\title{
Pengaruh Konflik Pekerjaan-Keluarga Terhadap Kepuasan Kerja (Kasus Karyawan Bank BJB Cabang Utama Bandung)
}

\author{
Afina Azka Yasyifa ${ }^{1 *}$ dan Sri Raharso ${ }^{2}$ \\ ${ }^{1}$ Jurusan Administrasi Niaga, Politeknik Negeri Bandung, Indonesia \\ ${ }^{2}$ Jurusan Administrasi Niaga, Politeknik Negeri Bandung, Indonesia
}

\begin{abstract}
:
The current business organization is important to review the conflict between work and family. It can impact on the survival of employees in business organizations. Work-family conflicts can be one reason employee dissatisfaction with work. The relationship between work-family conflict and job satisfaction. Based on research conducted on 118 respondents employees Bank Bjb Office Main Branch Bandung, obtained results that show there is a relationship between work family conflict with job satisfaction. This is evidenced by the results of correlation analysis between work family conflict variables with job satisfaction included in the negative and significant relationship. Furthermore, work family conflict also has a negative effect on job satisfaction in the regression analysis done.
\end{abstract}

Keywords: business organization, job satisfaction, work family conflict

\section{PENDAHULUAN}

Bisnis perbankan saat ini merupakan salah satu akses dalam mengembangkan dunia usaha. Hal ini dibuktikan adanya eksistensi dan aktivitas perbankan yang mampu memberikan kemudahan bagi para pelaku usaha untuk melakukan berbagaikontrak kerja, diantaranya tidak lagi hanya berfokus pada price competition namun juga berfokus pada non price competition yang lebih menekankan kepada peningkatan pelayanan, kemampuan berinteraksi dengan pelanggan, serta menjangkau pendistribusian produk baik barang maupun jasa secara luas dalam meraih kedudukan sebagai perusahaan yang unggul.

Persaingan non price competition menyebabkan pelaku usaha di industri

*Emailkorespondensi:

Afina Azka Yasyifa

afinaflix@gmail.com perbankan menciptakan keunggulan bersaing melalui sumber daya manusia yang mampu memberikan performa kerja lebih baik dalam melayani pelanggan. Sumber daya manusia merupakan salah satu elemen utama yang menempati posisi sangat strategis dalam organisasi atau perusahaan perbankan, artinya unsur manusia memegang peranan untuk menjalankan aktivitas sehingga dapat mencapai apa yang telah menjadi target tujuan (Adhani, 2013).

PT Bank Pembangunan Daerah Jawa Barat Tbk merupakan salah satu bentuk badan usaha yang bergerak dalam bidang perbankan.Dilansir dari media online bankbjb.co.id (2017) PT Bank Pembangunan Daerah Jawa Barat Tbk pada tahun 2017 telah berhasil meraih banyak penghargaan, salah satunya adalah sebagai Bestof The Best dari Forbes Indonesia dengan peringkat ke18 dari 50 perusahaan serta dua lainnya yaitu 
meraih penghargaan Excellent Service Experience Award ESEA dalam kategori Good Performance In Delivering Positive Customer Experience dan Top 5 Best Consumer Choice Regional Development Bank yang diselenggarakan oleh Warta Ekonomi.

PT Bank Pembangunan Daerah Jawa Barat Tbk sebagai salah satu perusahaan perbankan yang mampu memberikan citra baik di mata publik. Berkaitan dengan pentingnya kinerja karyawan dalam mencapai tujuan perusahaan, maka berbagai cara dilakukan untuk meningkatkan kinerja karyawan, salah satu hal yang paling penting adalah menciptakan kepuasan kerja yang konsisten bagi karyawan.

Karyawan dapat bekerja secara produktif dengan berbagai dorongan seperti pekerjaan yang sesuai dengan apa yang diharapkan, penghargaan yang diberikan dari pihak perusahaan, dan karyawan yang merasa puas akan pekerjaannya.Untuk menciptakan kepuasan kerja, tentu pihak manajemen harus menentukan faktor pendukung yang mampu memberikan rasa kepuasan kerja terhadap karyawan.

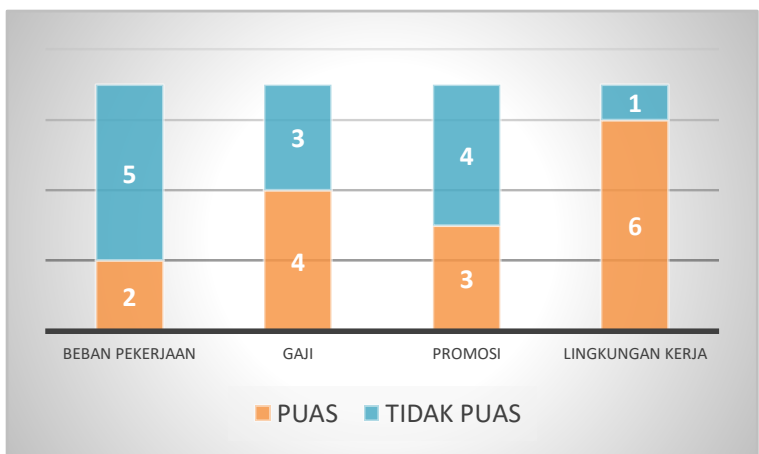

Sumber: data olahan (2018)

Gambar 1. Tingkat Kepuasan Karyawan Bank Bjb Cabang Utama Bandung

Berdasarkan Gambar 1, hasil wawancara yang dilakukan pada saat praktik kerja lapangan tanggal 15 Maret 2018 kepada 7karyawan Bank Bjb Cabang Utama Bandung, 5 responden mengaku beban pekerjaan yang tinggi merupakan salah satu aspek karyawan merasa tidak puas dengan pekerjaannya saat ini, terutama pada saat akhir bulan dimana bank melakukan pencatatan seluruh transaksi, kemudian karyawan yang menjabat di bagian marketing mempunyai target-target untuk mendapatkan nasabah, sertadeadline dengan jangka waktu yang pendek mengharuskan para karyawan mengerahkan tenaga yang lebih untuk menuntaskan pekerjaannya, bahkan tujuh responden mengaku sering mengambil waktu lembur untuk bekerja pada saat weekend.

Selain itu 4 dari 7 responden mengaku puas dengan timbal balik perusahaan berupa gaji yang diberikan tiap bulannya, karyawan menganggap seperti tunjangan hari raya serta tunjangan akhir tahun mampu memberikan kepuasan terhadap karyawan. 6 dari 7responden pun menjawab puas dengan lingkungan mereka bekerja, salah satu faktornya adalah sifat kekeluargaan diantara rekan kerja, serta manajer yang mampu menciptakan komunikasi antara atasan dan bawahan secara baik. Selanjutnya dilihat dari aspek promosi, 4 dari 7 responden mengaku tidak puas, dikarenakan adanya penilaian kinerja yang ketat dari atasan.

Keseimbangan antara kerja dengan kehidupan di dalam pekerjaan merupakan faktor penting yang perlu dipertimbangkan oleh perusahaan dalam membuat suatu kebijakan agar produktivitas kerja tetap terjaga (Maslichah \& Hidayat, 2017). Salah satu yang mampu dijadikan sebagai faktor penentu karyawan dapat menyeimbangkan antara pekerjaan dengan kehidupan adalah keseimbangan waktu (Hudson, 2005).

Adanya kebijakan pembukaan jadwal pelayanan operasional bank setiap hari Sabtu dan Minggu (weekend banking) di kantor Bank Bjb Cabang Utama Bandung menyebabkan karyawan yang bertugas 
sebagai teller, customer service, serta supervisor operasional merasakan pekerjaan yang dilakukan di hari libur menyita waktu untuk keluarga ataupun waktu yang dapat dihabiskan secara personal. Hal ini menjadikan karyawan sulit dalam membagi waktu antara pekerjaan dan kehidupan.

Dapat dikatakan dengan tidak seimbangnya waktu karyawan antara pekerjaan dengan kehidupan berdampak pada timbulnya konflik, salah satunya adalah konflik pekerjaan keluarga (work family conflict).

Hal ini selaras dengan pendapat Putri (2013) yang menyatakan bahwa keterbatasan waktu yang dimiliki oleh seseorang, yaitu waktu yang dipergunakan untuk pekerjaan, seringkali berakibat terbatasnya waktu untuk keluarga, ketegangan dalam suatu peran yang akhirnya memengaruhi kinerja peran yang lain sehingga dibutuhkan penyeimbangan peran dalam pekerjaan dan keluarga untuk mencapai suatu kepuasan. Peran keluarga berhubungan dengan tekanan yang timbul dalam menangani urusan rumah tangga dan menjaga anak, sedangkan peran dalam pekerjaan berhubungan dengan tekanan yang timbul dari beban kerja yang berlebihan dan waktu yang dibutuhkan, misalnya pekerjaan yang harus segera diselesaikan. Menurut Greenhaus dan Beutell (1985) seseorang yang sudah menikah lebih sering mengalami konflik pekerjaan keluarga dibandingkan yang belum mempunyai status pernikahan. Seseorang yang telah menikah akan memiliki tanggung jawab yang lebih besar dibandingkan yang belum menikah. Oleh karena itu status perkawinan dapat menjadi salah satu faktor penentu adanya konflik pekerjaan-keluarga yang dapat dirasakan oleh karyawan. Berikut Gambar 2:

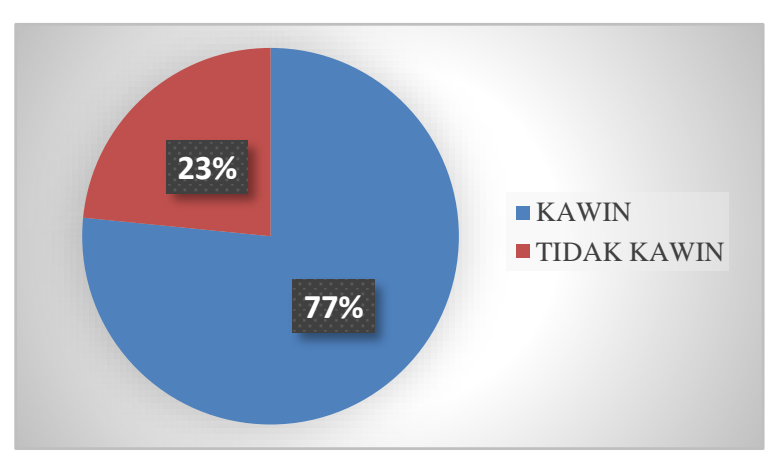

Sumber: Bagian Umum Bank Bjb Cabang Utama Bandung (2016)

Gambar 2. Status Karyawan Kantor Cabang Utama Bank Bjb Kota Bandung

Berdasarkan diagram diatas, jumlah persentase karyawan yang sudah menikah adalah $77 \%$, selanjutnya karyawan yang belum mempunyai status pernikahan sebanyak 23\%. Berdasarkan jumlah tersebut Bank Bjb Cabang Utama Bandung lebih banyak memiliki karyawan yang sudah menikah, tentu hal ini dapat menjadi salah satu indikasi adanya konflik pekerjaan dan keluarga yang dirasakan oleh karyawan.

Hal ini diperkuat dengan hasil wawancara kepada 5 orang karyawan yang sudah memiliki status perkawinan. 3 responden yang belum mempunyai anak mengaku sering merasakan konflik akibat waktu yang diberikan untuk pasangan lebih sedikit dibandingkan dengan waktu untuk bekerja, dengan alasan rutinitas yang dilakukan di tempat kerja sering mengganggu aktivitas di rumah, seperti jam pulang kantor yang lebih malam maupun aktivitas pekerjaan di luar hari kerja operasional, dengan permasalahan tersebut tidak jarang responden sulit untuk memberikan perhatian yang lebih baik kepada pasangannya.

Selanjutnya 2 responden yang sudah memiliki anak sering merasakan konflik akibat kurangnya memberikan pengawasan serta mendidik anak secara langsung. Selain itu, responden menjelaskan pasangan yang baru menikah atau baru menjalani status 
pernikahannya sering mengalami konflik pekerjaan-keluarga, seperti tidak adanya dukungan moril yang diberikan pasangan, serta pasangan suami istri yang memilih untuk bekerja sehingga munculnya perdebatan akibat kurangnya komunikasi.

Berdasarkan hasil dari pemaparan diatas, dapat diindikasikan bahwa ketidakpuasan kerja yang dipengaruhi oleh adanya konflik pekerjaan-keluarga. Hal ini selaras dengan pendapat menurut Soeharto (2010) bahwa hubungan antara konflik pekerjaan-keluarga berhubungan negatif, dimana semakin tinggi tingkat konflik pekerjaa-keluarga, semakin rendah tingkat kepuasan kerja karyawan.

Oleh sebab itu penelitian ini berfokus pada perilaku organisasi yang berjudul "Pengaruh Konflik Pekerjaan-Keluarga (Work Family Conflict) Terhadap Kepuasan Kerja (Job Satisfaction)".

\section{Perumusan Masalah}

Berdasarkan latar belakang yang telah dipaparkan, perumusan masalah dalam penelitian ini adalah:

1. Bagaimana tingkat konflik pekerjaankeluarga (work family conflict) yang dirasakan pegawai di Bank Bjb Cabang Utama Bandung.

2. Bagaimana tingkat kepuasan kerja (job satisfaction) pegawai di Bank Bjb Cabang Utama Bandung.

3. Bagaimana pengaruh konflik pekerjaankeluarga (work family conflict) terhadap kepuasan kerja (job satisfaction) pegawai di Bank Bjb Cabang Utama Bandung.

\section{Tujuan Penelitian}

Dari rumusan masalah yang dipaparkan, tujuan penelitian ini dilakukan untuk mengetahui:
1. Mengetahui tingkat konflik pekerjaankeluarga (work family conflict) yang dirasakan pegawai di Kantor Cabang Utama Bank BJB Kota Bandung.

2. Mengetahui tingkat kepuasan kerja (job satisfaction) pegawai di Kantor Cabang Utama Bank BJB Kota Bandung.

3. Mengetahui apakah terdapat pengaruh antara konflik pekerjaan-keluarga (work family conflict) terhadap kepuasan kerja (job satisfaction) pegawai di Kantor Cabang Utama Bank BJB Kota Bandung.

\section{Hipotesis}

Berdasarkan pembahasan yang ada pada pendahuluan,dapat disimpulkan bahwa hipotesis penelitian adalah sebagai berikut:

$\mathrm{H}_{0}$ : Tidak terdapat pengaruh antara konflik pekerjaan-keluarga terhadap kepuasan kerja karyawan Bank BjbCabang Utama Bandung.

$\mathrm{H}_{\mathrm{a}}$ :Terdapat pengaruh antara konflik pekerjaan-keluarga terhadap kepuasan kerja karyawan Bank Bjb Cabang Utama Bandung.

\section{KAJIAN LITERATUR}

\section{Konflik Pekerjaan-Keluarga}

Menurut Aboobaker \& Edward (2017) pekerjaan dan keluarga adalah dua peranan yang menuntut jumlah energi yang sama, waktu dan tanggung jawab. Permasalahan konflik antara pekerjaan dan keluarga merupakan sebuah tantangan bagi individu maupun organisasi. Hal ini menjadi sebuah latar belakang adanya pembahasan konflik pekerjaan keluarga dalam lingkup perilaku organisasi maupun sumber daya manusia. Konflik pekerjaan keluarga merupakan topik dimana mampu menjadi perhatian bagi lingkup manajemen dalam memerhatikan kelangsungan hidup karyawan. 
Work family conflictsebagai bentuk konflik peran dimana peran di dalam keluarga dan di pekerjaan menuntut satu sama lain sehingga perlu adanya tanggung jawab dan kebutuhan peran di dalam keduanya (Frone, 2000). Walaupun kedua lingkungan tersebut menuntut peran serta waktu yang berbeda, keluarga serta pekerjaan merupakan dua lingkungan yang mempunyai keterkaitan satu dengan yang lain (Christine dan Oktorina, 2010). Konflik pekerjaan keluarga ini muncul karena adanya perbedaan antara kenyataan dan ekpestasi yang dihadapkan seseorang, dimana hal ini berdampaka pada peran di keluarga maupun di pekerjaan (Amelia, 2010). Selain itu, konflik pekerjaan keluarga merupakan bentuk konflik peran yang muncul akibata adanya perbedaant tuntutan dari berbagai lingkunga, sehingga seseorang mengalami kesulitan dalam pembagian waktu serta perannya Tolly (2001).

Dampak adanya konflik pekerjaankeluarga yang dirasakan oleh karyawan akan menciptakan hasil yang tidak diingikan seperti stres, tubuh yang tidak sehat, absensi menutun, serta turnover karyawan yang tinggi (Ghayyur dan Jamal, 2012).

\section{Kepuasan Kerja}

Menurut Kaswan (2017: 192) kepuasan kerja adalah bentuk dari adanya ketidaksesuaian antara apa yang diinginkan dengan apa yang terjadi, sehingga bentuk kepuasan kerja dirasakan oleh karyawan berbeda-beda. Kepuasan kerja juga dijelaskan oleh Kinicki dan Fugate (2012: 161), bahwa "Job satisfaction is an affective or emotional response towards various facets of one's job". Kepuasan kerja merupakan peranan yang sangat penting demi terciptanya tujuan perusahaan. Kepuasan kerja mampu membentuk semangat serta keterikatan loyalitas karyawan terhadap perusahaan ia bekerja (Siagian, 2002). Menurut Handoko (1996), kepuasan kerja adalah pandangan dari seseorang apakah pekerjaanya saati menyenangkan atau tidak menyenangkan. Sehingga dapat disimpulkan bahwa bahwa kepuasan kerja merupakan bentuk dari emosional dan efektif yang dirasakan berbeda-beda oleh setiap karyawan dari pekerjaannya saat ini.

Menurut Robbins \& Judge (2013) kepuasan kerja menuntut adanya interaksi dengan rekan kerja, atasan, mengikuti aturan danpuaskebijakan organisasi, memenuhi standar kinerja, hidup pada kondisi kerja yang sering kurang ideal dan lain-lain.

Banyaknya pendapat para ahli mengenai kepuasan kerja menunjukkan bahwa job satisfaction bukan merupakan konsep tunggal. Seseorang dapat relatif puas dengan salah satu aspek pekerjaan dan tidak puas dengan satu atau lebih aspek lainnya. Artinya, kepuasan kerja seorang karyawan tidak bisa ditilik dari keseluruhan, tentunya dilihat dari dimensi yang ada pada setiap pekerjaan yang dilakukan.

Karyawan yang merasa tidak puas akan pekerjaannya saat ini akan terlihat dari cara ia bekerja seperti kurang semangat, emosi yang tidak terkendali, cepat lelah serta tingkat absensi yang tinggi. Berbeda halnya dengan karyawan yang merasa puas akan pekerjaannya saat ini. Hal ini terlihat dari adanya kontribusi kerja yang baik, serta selalu bersemangat untuk bekerja.

\section{Kerangka Pemikiran}

Berikut kerangka pemikiran yang menjelaskan hubungan antara variabel $\mathrm{x}$ yaitu konflik pekerjaan-keluarga dengan variabel y yaitu kepuasan kerja. Berikut ini Gambar 3. yang menjelaskan mengenai kerangka pemikiran penelitian ini: 


\begin{tabular}{|c|c|}
\hline $\begin{array}{c}\text { Variabel X } \\
\text { Work Family } \\
\text { Conflict } \\
\text { Netemeyer } \text { et al., } \\
\text { (1996) }\end{array}$ & $\longrightarrow$ \\
- Variabel Y \\
Job Satisfaction \\
Spector (1997) \\
dalam (Watson et \\
al., 2007) \\
Conflict \\
- Family Work \\
Conflict \\
\end{tabular}

Gambar 3.Kerangka Pemikiran

\section{METODE PENELITIAN}

Objek penelitian ini mengenai perilaku organisasi yang berfokus pada konflik pekerjaan-keluarga dan kepuasan kerja karyawan Bank Bjb Cabang Utama Bandung, berjumlah 174 karyawanyang terdiri dari 10 kantor cabang pembantu dan 6 kantor kas.

Pada penelitian ini, pengumpulan data primer menggunakan metode penelitian survei deskriptif. Metode survei merupakanmetode pengumpulan data primer yang menggunakan pertanyaan lisan dan tulisan (Riduan, 2014). Metode survei yang dilakukan dalam penelitian dengan menggunakan penyebaran kuesioner. Pada penelitian ini menggunakan metode penelitian yang menggunakan metode penelitian kuantitatif. Hubungan variabel yang digunakan dalam metode penelitian kuantitatif adalah hubungan sebab akibat, sehingga dalam penelitiannya terdapat variabel independen dan dependen. Variabel tersebut dicari seberapa besar pengaruh variabel independen terhadap variabel dependen (Sugiyono, 2013: 11).

Dalam penelitian ini yang merupakan variabel bebas (independent variable) adalah konflik pekerjaan-keluarga (work family conflict). Sedangkan variabel terikat (dependent variable) adalah variabel yang dipengaruhi atau menjadi akibat karena adanya variabel lain (variabel bebas). Variabel dependen dalam penelitian ini adalah kepuasan kerja (job satisfaction).

Dalam menentukan jumlah populasi, penelitian ini menggunakan rumus Slovin denganpopulasi 174 karyawan, maka didapat sampel sebanyak 117,96 yang dibulatkan menjadi 118 karyawan. Data yang digunakan adalah data primer yang berasal dari hasilwawancara dan kuesioner. Data sekunder digunakan sebagai pengetahuan dalam menjawab masalah penelitian yang didapat dari buku dan jurnal.

\section{HASIL DAN PEMBAHASAN}

Sebanyak 118 kuesioner disebarkan kepada responden yaitu karyawan Bank Bjb Cabang Utama Bandung. Adapun gambaran tentang responden penelitian ini sebagai berikut:Komposisi demografis dapat diklasifikasikan berdasarkan jenis kelamin, usia, lama bekerja, status pernikahan, serta posisi manajerial. Berikut adakah tabel profil demografi responde yang dapat dilihat pada tabel 1 berikut.

Berdasarkan tabel 1. dapat diketahui bahwa sebagian besar dari responden berjenis kelamin wanita dengan jumlah 70 orang, kemudian usia dengan rentang 20-30 tahun merupakan rentang usia terbesar dari keseluruhan responden dengan jumlah 86 orang atau $73 \%$. Dilihat dari data lama bekerja, 3-4 tahun dengan 5-6 tahun tidak begitu memiliki jumlah perbedaan yang jauh, dimana hanya memiliki selisih 3 angka. Sedangkan dengan data status pernikahan, responden yang sudah menikah lebih mendominasi dengan jumlah persentase $69 \%$, serta posisi manajerial sebagai staff merupakan responden terbanyak dengan persentase melebihi angka $80 \%$. 
Tabel 1. Profil Demografi Responden

\begin{tabular}{lcc}
\hline \multicolumn{1}{c}{ Data } & Frekuensi & $\begin{array}{c}\text { Persentase } \\
(\%)\end{array}$ \\
\hline Jenis Kelamin: & & \\
Pria & 48 & 41 \\
Wanita & 70 & 59 \\
\hline Usia: & & \\
20-30 Tahun & 86 & 73 \\
31-40 Tahun & 29 & 24 \\
41-50 Tahun & 2 & 2 \\
>50 Tahun & 1 & 1 \\
\hline Lama Bekerja: & & \\
3-4 Tahun & 45 & 38 \\
5-6 Tahun & 42 & 36 \\
>6 Tahun & 31 & 26 \\
\hline Status: & & \\
Menikah & 81 & 69 \\
Belum Menikah & 37 & 31 \\
\hline Posisi Manajerial: & & \\
Staf & 103 & 87 \\
Supervisor & 9 & 8 \\
Manajer Tingkat & 6 & 5 \\
Menengah & & \\
Sumber: Data Primer diolah (2018) &
\end{tabular}

Uji validitas dilakukan dengan menggunakan program SPSS version 22.0. Biasanya syarat minimum untuk dianggap memenuhi syarat adalah jika $r>0,30$, Apabila skor total kurang dari 0.30 maka butir dalam instrumen tersebut dinyatakan tidak valid, sehingga harus diperbaiki atau dibuang. Berdasarkan hasil uji validitas di konflik pekerjaan-keluarga serta kepuasan kerja seluruh instrumen penelitian dinyatakan valid karena nilai yang ada pada kolom corrected item-total correlation $\geq$ 0,300. Tabel 2 dan tabel 3 adalah dari hasil uji validitas variabel konflik pekerjaankeluarga dengan kepuasan kerja.

Uji reliabilitas kemudian dilakukan untuk mengetahui sejauh mana tingkat kehandalan data yang diperoleh untuk diteliti. Skor hasil pengukuran dapat dipercaya dari kekeliruan pengukuran (measurement error) dengan teknik yang paling umum digunakan adalah Alpha Cronbanch (Indrawati, 2015).
Tabel 2. Uji Validitas Variabel X

\begin{tabular}{lc}
$\begin{array}{c}\text { Konflik Pekerjaan- } \\
\text { Keluarga }\end{array}$ & $\begin{array}{c}\text { Corrected Item- } \\
\text { Total Correlation }\end{array}$ \\
\hline WFC 1 & 0,678 \\
\hline WFC 2 & 0,634 \\
\hline WFC 3 & 0,681 \\
\hline WFC 4 & 0,675 \\
\hline WFC 5 & 0,581 \\
\hline FWC 1 & 0,551 \\
\hline FWC 2 & 0,569 \\
\hline FWC 3 & 0,472 \\
\hline FWC 4 & 0,462 \\
\hline FWC 5 & 0,527 \\
\hline \multicolumn{2}{c}{ Sumber : data olahan $(2018)$}
\end{tabular}

Tabel 3. Uji Validitas Variabel Y

\begin{tabular}{lc}
\hline Kepuasan Kerja & $\begin{array}{c}\text { Corrected Item-Total } \\
\text { Correlation }\end{array}$ \\
\hline JS 1 & 0,404 \\
\hline JS 2 & 0,480 \\
\hline JS 3 & 0,540 \\
\hline JS 4 & 0,549 \\
\hline JS 5 & 0,587 \\
\hline JS 6 & 0,310 \\
\hline JS 7 & 0,353 \\
\hline JS 8 & 0,307 \\
\hline JS 9 & 0,607 \\
\hline JS 10 & 0,331 \\
\hline JS 11 & 0,339 \\
\hline JS 12 & 0,320 \\
\hline JS 13 & 0,414 \\
\hline JS 14 & 0,323 \\
\hline JS 15 & 0,390 \\
\hline JS 16 & 0,410 \\
\hline JS 17 & 0,575 \\
\hline JS 18 & 0,564 \\
\hline JS 19 & 0,507 \\
\hline JS 20 & 0,553 \\
\hline JS 21 & 0,490 \\
\hline JS 22 & 0,349 \\
\hline JS 23 & 0,542 \\
\hline JS 24 & 0,410 \\
\hline & Sumber: data olahan $(2018)$ \\
\hline
\end{tabular}

Tabel 4. Hasil Uji Reliabilitas Variabel Penelitian

\begin{tabular}{ccc}
\hline Variabel & $\begin{array}{c}\text { N of } \\
\text { item }\end{array}$ & $\begin{array}{c}\text { Cronbach's } \\
\text { Alpha }\end{array}$ \\
\hline $\begin{array}{c}\text { Konflik Pekerjaan- } \\
\text { Keluarga }\end{array}$ & 10 & 0,869 \\
\hline Kepuasan Kerja & 24 & 0,872 \\
\hline
\end{tabular}

Sumber: data olahan (2018) 
Menurut Noor (2014) jika nilai Alpha $>$ 0,60 disebut reliabel. Berdasarkan Tabel 4. Hasil uji reliabilitas dapat disimpulkan bahwa variabel konflik pekerjaan-keluarga dan kepuasan kerja reliabel karena sudah melebihi angka 0,60.

Berdasarkan rumusan masalah maka variabel penelitian dibedakan menjadi variabel bebas (independent variable) dan variabel terikat (dependent variable). Untuk mengetahui pengaruh konflik pekerjaankeluarga teradap kepuasan kerja maka dapat dilihat pada model summary yang diolah pada program SPSS, khususnya pada tabel $\mathrm{R}$ square. Tabel 5 sebagai berikut:

\section{Tabel 5. Hasil Uji Regresi}

\begin{tabular}{lccc}
\hline & $\begin{array}{c}\text { Unstandardized } \\
\text { Beta Coefficients }\end{array}$ & T & Sig \\
\hline $\begin{array}{l}\text { Konflik } \\
\text { Pekerjaan- } \\
\text { Keluarga }\end{array}$ & $-0,659$ & $-6,095$ & 0,000 \\
\hline $\begin{array}{l}\text { Kepuasan } \\
\text { Kerja }\end{array}$ & 99,248 & $\begin{array}{c}36,20 \\
1\end{array}$ & 0,000 \\
\hline R Square & 0,243 & & \\
\hline $\begin{array}{l}\text { Adjusted } \\
\text { R Square }\end{array}$ & 0,236 & & \\
\hline F & 37,147 & \\
\hline Sig F & 0,000 \\
\hline
\end{tabular}

Berdasarkan angka $\mathrm{R}$ square $\left(\mathrm{R}^{2}\right)$ konflik pekerjaan-keluarga terhadap kepuasan kerja menunjukkan nilai 0,243. Konflik pekerjaan-keluarga mampu mempengaruhi kepuasan kerja sebesar $24,3 \%$. Sementara sisanya $75,7 \%$ dipengaruhi faktor-faktor lain yang tidak dijelaskan dalam penelitian ini.

Uji signifikansi simultan (uji statistik F) dapat disimpulkan bahwa nilai $\mathrm{F}$ hitung adalah 37,147. Sementara itu dengan df1 : 1 dan df2 : 118-1-1 = 116, maka didapat F tabel dengan nilai 3,92. Nilai tersebut mengimpretasikan bahwa nilai $\mathrm{F}$ hitung lebih besar dari nilai $F$ tabel. Hal ini dapat disimpulkan bahwa $\mathrm{H} 0$ ditolak dan $\mathrm{Ha}$ diterima.

Uji-t digunakan untuk membuktikan pengaruh yang signifikan antara variabel independen terhadap variabel dependen.

Apabila nilai t hitung lebih besar dari tabel atau hasil dari nilai signifikansi $<0.05$, maka hipotesis yang diajukan dapat diterima. Nilai t hitung dapat dilihat pada hasil regresi, dan nilai tabel didapat dengan signifikansi $\alpha$ : 0.05 dengan rukus df : $n-k$.

Uji signifikan parameter secara parsial (uji statistik t) menunjukkan Nilai t hitung work family conflict terhadap job satisfation menunjukkan hasil negatif yaitu 0,659 , sementara untuk $\mathrm{t}$ tabel dengan signifikansi $\alpha: 0.05$ dan df sebesar didapat $\mathrm{t}$ tabel sebesar 1,658. Nilai t hitung tersebut lebih besar dibanding $t$ tabel.

Begitupun dengan angka signifikansi yang menunjukkan nilai 0,000 yang artinya lebih kecil dari 0,005. Dengan demikian, Ha diterima dan Ho ditolak.

Hal ini berarti bahwa adanya pengaruh yang negatif dan signifikan antara work family conflict terhadap job satisfaction pada karyawan Bank Bjb Cabang Utama Bandung.

Berdasarkan Tabel 6. dapat ditarik kesimpulan bahwa variabel konflik pekerjaan-keluarga pada karyawan Bank Bjb Cabang Utama Bandung termasuk dalam kategori rendah. Hal ini menunjukkan secara keseluruhan karyawan Bank Bjb Cabang Utama Kota Bandung tidak mengalami konflik antara pekerjaan dan keluarga.

Tabel 6. Statistik Deskriptif

\begin{tabular}{lccccc}
\hline & N & Min & Max & Mean & $\begin{array}{c}\text { Std. } \\
\text { Deviat } \\
\text { ion }\end{array}$ \\
\hline $\begin{array}{l}\text { Konflik } \\
\text { pekerjaan- } \\
\text { keluarga }\end{array}$ & 118 & 1 & 5 & 2,44 & 0,669 \\
\hline $\begin{array}{l}\text { Kepuasan } \\
\text { Kerja }\end{array}$ & 118 & 2 & 4 & 3,48 & 0,445 \\
\hline $\begin{array}{l}\text { Sumber: data olahan (2018) } \\
\text { Kumber }\end{array}$ & & & & \\
\hline
\end{tabular}


Meskipun variabel konfik pekerjaankeluarga ini termasuk pada kategori rendah, namun terdapat satu dimensi yaitu work family conflictyang termasuk dalam kategori cukup tinggi. Hal ini dapat menjadi gambaran bahwa karyawan Bank Bjb Cabang UtamaBandung mengalami konflik yang berkaitan dengan pekerjaan yang mengganggu tanggung jawab pada keluarga. Sementara itu dimensi family work conflict termasuk ke dalam kategori rendah. Hal ini dapat disimpulkan bahwa karyawan Bank Bjb Cabang UtamaBandung tidak mengalami konflik yang berkaitan dengan tanggung jawab terhadap keluarga.

Hal ini berarti menunjukkan tuntutan serta tekanan dari pekerjaan tidak memberatkan karyawan untuk mencurahkan sebagian waktu dan energinya pada pekerjaan sehingga dalam hal ini, karyawan Bank Bjb Cabang UtamaBandung tidak mempunyai permasalahan dengan adanya tuntutan serta tekanan dari pekerjaan yang dapat mengganggu tanggung jawabnya terhadap aktivitas di dalam keluarga.

Dalam pernyataan lain yang mengarah pada konflik pekerjaan keluarga, indikator ketiga mempunyai rata-rata sebesar 2,59. Hal ini menunjukkan indikator ketiga termasuk pada kategori rendah dimana yaitu "Kegiatan yang ingin saya lakukan di rumah tidak bisa dikerjakan karena tuntutan pekerjaan". Hal ini pula menjelaskan bahwa kegiatan selama di dalam pekerjaan tidak sepenuhnya mengganggu kehidupan karyawan di tengah keluarga.

Lain halnya dengan pernyataan dari indikator kedua dan kelima yang memiliki rata-rata di dalam kategori "cukup tinggi" dimana mempunyai angka 2,64 dan 3,00. Pernyataam kedua yaitu "Waktu yang dibutuhkan untuk bekerja mempersulit saya memenuhi tanggung jawab di dalam keluarga" serta pernyataan kelima yaitu
"Tuntutan dari pekerjaan membuat saya mengubah rencana kegiatan untuk keluarga".

Hasil tersebut selaras dengan keadaan yang terjadi di lapangan. Sebagai contoh, Kantor Bank Bjb Cabang Pembantu Asia Afrika yang dibawahi oleh Kantor Bank BjbCabang Utama Bandung membuka jasa pelayanan weekend banking dimana setiap hari Sabtu dan Minggu sebagian karyawan yang bekerja sebagai customer service, teller, serta supervisor dituntut untuk bekerja, disaat dua hari itu merupakan waktu yang bisa dihabiskan dengan keluarga.

Selain itu berdasarkan dari hasil wawancara dengan beberapa karyawan, adanya jadwal piket ATM service mampu menyita sebagian waktunya. Sebagai contohnya adalah pada saat hari lebaran beberapa karyawan mendapatkan tugas ATM service dimana pekerjaan tersebut yaitu untuk memastikan ATM yang dibawahi Kantor Bank Bjb Cabang Utama Kota Bandung mempunyai saldo yang cukup untuk digunakan para nasabah. Tentu kendala tersebut mampu menyita waktu serta kegiatan yang berkaitan dengan keluarga.

Menurut Baltes \& Heydens-Gahir (2003) konflik pekerjaan-keluarga terdiri dari 3 faktor, salah satunya adalah time-based demands yang artinya adanya keterbatasan waktu yang dipergunakan untuk pekerjaan seringkali berakibat terbatasnya waktu untuk keluarga dan sebaliknya. Waktu yang dihabiskan serta kegiatan yang datang dari arah pekerjaan tentu mengganggu tugas dan tanggung jawab karyawan untuk keluarga. Karyawan yang terikat dengan pekerjaan dimungkinkan terdapat dua hal yang mempengaruhi yaitu tuntutan kerja dan sumber daya kerja. Hal ini sesuai dengan pernyataan menurut Bakker (2010) yaitu tuntutan kerja adalah segala aspek fisik, psikologis, sosial dan organisasional dari sebuah pekerjaan yang membutuhkan usaha 
dan keterampilan fisik dan psikis secara berkelanjutan, sehingga membutuhkan pengorbanan fisik dan psikologis tertentu. Berdasarkan hasil tersebut dapat diketahui bahwa karyawan memiliki masalah dengan adanya keterikatan waktu terhadap pekerjaan serta kegiatan yang dihabiskan di dalam kantor mengakibatkan karyawan merasakan konflik pekerjaan terhadap keluarga.

Secara keseluruhan tingkat kepuasan kerja di Bank Bjb Cabang Utama Bandung sudah sangat baik, hal ini dapat digambarkan pada tabel 6. yang menjelaskan bahwa variabel kepuasan kerja termasuk pada kategori tinggi. Walaupun termasuk kategori tinggi, namun ada beberapa dimensi dari variabel kepuasan kerja yang perlu di tingkatkan kembali yaitu dimensi fringe benefitsserta dimensi operating conditions.

Dimensi fringe benefits atau tunjangan ini memiliki nilai rata-rata sebesar 3,13. Nilai rata-rata tersebut masuk kedalam kategori "Cukup Tinggi", dan nilai mean tersebut adalah nilai mean terendah dari variabel kepuasan kerja. Menurut Luthans (2011) individu merasa puas karena sistem penggajian yang seimbang antara produktivitas yang dikeluarkan dengan imbalan yang diterima. Dimensi fringe benefits mempunyai empat indikator diantaranya terdapat indikator dengan nilai rata-rata tertinggi yaitu indikator pertama yang menyatakan "Saya puas dengan tunjangan yang diberikan oleh organisasi ini" dengan nilai rata-rata 3,24. Nilai rata-rata tersebut termasuk pada kategori "Cukup Tinggi”. Menurut Bisen \& Priya (2010) tunjangan merupakan salah satu faktor organisasi yang mempengaruhi kepuasan kerja. Kelompok dengan penghasilan rendah dan tinggi akan mempunyai tingkat kepuasan yang lebih rendah dibandingkan dengan kelompok penghasilan menengah yangmempunyai tingkat kepuasan yang lebih tinggi.

Dimensi operating conditions merupakan dimensi ketiga yang ada pada variabel kepuasan kerja. Dimensi ini merupakan salah satu dimensi yang termasuk pada kategori "Cukup Tinggi” dengan nilai rata-rata 3,14. Dimensi ini mempunyai empat indikator pernyataan yang menjelaskan tentang kondisi pekerjaan karyawan selama dikantor seperti prosedur, birokrasi, serta karyawan merasa melakukan banyak pekerjaan dan mempunyai banyak dokumen pekerjaan.

Indikator pertama yang menyatakan "Banyaknya aturan dan prosedur mempersulit saya dalam bekerja" mempunyai nilai rata-rata sebesar 3,42. Nilai rata-rata tersebut termasuk pada kategori "Tinggi" karena berada pada kelas interval 3,41-4,20. Indikator pertama ini merupakan indikator yang mempunyai nilai rata-rata tertinggi dari semua indikator yang ada pada dimensi operating conditions. Selanjutnya indikator kedua, ketiga dan keempat merupakan indikator yang termasuk pada kategori "Cukup Tinggi” Indikator ketiga dan keempat mempunyai nilai rata-rata 2,88 dan 2,99. Dimana indikator ketiga menyatakan "Saya melakukan banyak pekerjaan di kantor" sedangkan indikator keempat menyatakan "Saya mempunyai banyak dokumen pekerjaan".

Kondisi kerja merupakan memiliki dampak moderat terhadap kepuasan kerja. Jika kondisi kerja baik karyawan akan mudah melaksanakan pekerjaan. Jika lingkungan kerja kurang baik akan menyulitkan penyelasaian pekerjaan (Luthans, 2013). Dengan kata lain, kondisi pekerjaan menentukan faktor kepuasan karyawan. Selain itu pekerjaan itu sendiri dapat membuat individu seorang karyawan merasa 
puas, ia menikmati pekerjaannya sendiri tampa terpengaruh oleh faktor lain.

Dimensi yang keempat adalah dimensi co-workers. Dimana dimensi ini terdapat empat indikator pernyataan yang menjelaskan mengenai hubungan karyawan dengan rekan kerja. Secara keseluruhan dimensi co-workers mempunyai rata-rata yang tergolong "Tinggi" dengan nilai mean 3,56. Hal ini berada pada kelas interval 3,414,20. Indikator tertinggi pada dimensi ini adalah indikator pertama yang menyatakan "Saya menyukai rekan kerja saya" dengan nilai rata-rata 3,84 yang termasuk pada kategori "Tinggi". Selanjutnya indikator kedua yang menyatakan "Saya merasa harus bekerja lebih keras karena ketidakmampuan rekan kerja" mempunyai nilai rata-rata 3,22 "Cukup Tinggi" dimana hasil tersebut merupakan hasil terendah dari keempat indikator pada dimensi co-workers. Selanjutnya pernyataan ketiga yang menyatakan "Saya merasa nyaman bekerja dengan rekan kerja" mempunyai nilai ratarata sebesar 3,78 yang termasuk pada kategori "Tinggi", dan pernyataan terakhir adalah "Saya merasa ada perselisihan antar rekan kerja di perusahaan ini" termasuk pada kategori "Cukup Tinggi".

Menurut Kaswan (2017) semakin pegawai terhubung dengan rekan kerjanya, mereka akan mengembangkan hubungan persona dan sosial yang berkontribusi terhadap perasaan puas di tempat kerja. Berdasarkan hasil dari analisis deskriptif yang dipaparkan diatas, karyawan Bank Bjb Cabang Utama Kota Bandung merasa puas terhadap hubungan dengan rekan kerja di kantor, dimana karyawan menyukai dan merasa nyaman bekerja dengan rekan kerjanya sendiri. Hal ini sesuai dengan hasil wawancara yang dilakukan bahwa karyawan mengaku menyukai lingkungan kerja mereka, salah satu nya adalah rekan kerja.
Merujuk pada gambar 1. yang menjelaskan tingkat kepuasan karyawan Bank Bjb Cabang Utama Kota Bandung, 6 dari 7 responden menjawab puas dengan lingkungan mereka bekerja, salah satu faktornya adalah sifat kekeluargaan diantara rekan kerja.

Dimensi kelima adalah nature of work. Dimensi ini mempunyai empat indikator pernyataan yang menjelaskan tentang sifat kerja itu sendiri, baik dari rasa kebanggaan dengan pekerjaan hingga rasa puas karyawan terhadap pekerjaan yang mereka hadapi. Secara keseluruhan dimensi nature of work mempunyai nilai rata-rata yang terbilang “Tinggi”. Dimensi nature of work mempunyai nilai rata-rata sebesar 3,71 yang termasuk pada kelas interval antara 3,41-4,20.

Indikator yang mempunyai nilai ratarata tertinggi adalah indikator pertama yang menyatakan "Saya merasa pekerjaan di Bank Bjb kurang berarti" dengan hasil nilai ratarata 3,42. Walaupun angka ini termasuk pada kategori "Tinggi", namun hasil tersebut menjelaskan bahwa karyawan merasa pekerjaan yang saat ini dilakukan kurang berarti. Hal tersebut didukung dengan indikator yang mempunyai nilai rata-rata terendah yaitu pernyataan ketiga yang menyatakan "Saya merasa bangga dengan pekerjaan saat ini" dengan perolehan nilai rata-rata 2,88 serta pernyataan keempat yang menyatakan "Saya puas dengan pekerjaan saya di Bank Bjb" dengan nilai rata-rata 2,99. Kedua indikator tersebut berada pada kategori "Cukup Tinggi".

Nature of work meliputi dari kondisi kerja, keterampilan, lokasi kerja, serta pekerjaan itu sendiri. Menurut Bisen \& Priya (2010) jika pekerjaan dirotasi, karyawan memiliki sejumlah tugas yang harus dilakukan atau jika perubahan diperkenalkan di tempat kerja, hal itu akan mendatangkan kepuasan daripada hanya melakukan 
pekerjaa rutin. Selain itu berkenaan dengan nature of work atau sifat kerja, keterampilan merupakan salah satu faktor penentu rasa kepuasan kerja karyawan. Pekerjaan yang membutuhkan keterampilan mendatangkan perasaan puas yang kuat diantara para karyawan seperti makna, status dan tanggung jawab dipengaruhi oleh keterampilan pekerjaan. Semakin banyak karyawan melakukan pekerjaan terampil maka semakin puas karyawan tersebut (Bisen \& Priya, 2010).

\section{KESIMPULAN DAN SARAN \\ Kesimpulan}

Berdasarkan hasil dari pengumpulan data, pengolahan data serta analisis data yang sudah dilakukan, dapat ditarik kesimpulan yang sekaligus menjawab perumusan masalah dari penelitian yaitu sebagai berikut:

1. Tingkat dari konflik pekerjaan-keluarga pada karyawan Bank Bjb Cabang Utama Bandung berada pada kategori rendah. Walapun berada pada kategori rendah, namun terdapat satu dimensi yaitu work family conflict yang berada pada kategori cukup tinggi, kemudian dimensi yang lain yaitu family work conflict berada pada kategori rendah. Sehingga dapat diartikan bahwa karyawan Bank Bjb Cabang Utama Bandung memiliki potensi dalam merasakan konflik pekerjaan yang dapat mengganggu kehidupan atau tanggung jawab terhadap keluarga.

2. Tingkat kepuasan kerja pada karyawan Bank Bjb Cabang Utama Bandung berada pada kategori tinggi. Dimensi dengan nilai rata-rata tertinggi yaitu pada nature of work(sifat kerja), sedangkan nilai rata-rata terendah yaitu pada fringe benefits (tunjangan), meskipun mempunyai nilai rata-rata terendah, namun dimensi tersebut (tunjangan) mempunyai nilai rata-rata yang tergolong pada kelas interval cukup tinggi. Sehingga dapat diartikan bahwa karyawan Bank Bjb Cabang Utama Bandung memiliki kecenderungan rasa kepuasan terhadap pekerjaan. Meskipun secara keseluruhan karyawan merasa puas terhadap pekerjaannya, namun karyawan merasa pekerjaannya saat ini belum memenuhi ekspektasi. Hal ini terlihat dari beban pekerjaan dan tunjangan yang ada di Bank Bjb Cabang Utama Bandung.

3. Besarnya pengaruh konflik pekerjaankeluarga terhadap kepuasan kerja pada karyawan Bank Bjb Cabang Utama Bandung yaitu sebesar 24,3\%. Sisanya sebesar $75,7 \%$ dipengaruhi oleh faktorfaktor lain yang tidak dijelaskan dalam penelitian ini seperti beban kerja, stres kerja, turnover intentiondan lain sebagainya.

\section{Saran}

Sebagaimana penelitian yang sudah dilakukan, tentu ada beberapa masukan dan saran bagi Bank Bjb Cabang Utama Bandung untuk meningkatkan produktivitas dengan cara meningkatkan kualitas, efesiensi, dan efektivitas dari sumber daya manusia yang ada.

Konflik pekerjaan-keluarga menjadi salah satu penentu adanya rasa kepuasan terhadap pekerjaan itu sendiri. Menurut Yang et al., (2000) Tuntutan yang datangnya dari pekerjaan berhubungan secara langsung dengan waktu yang berlebih, serta tekanan dan beban pekerjaan yang tinggi, sedangkan tuntutan yang datangnya dari keluarga berhubungan dengan waktu dan peran untuk mengatur urusan rumah tangga serta mengurus anak. Hal ini tentunya dapat diatasi dengan cara membentuk program work life balance. Menurut Lockwood (2003) sebelum 
menciptakan program work life balance, pihak manajemen perlu mengetahui budaya organisasi Bank Bjb terlebih dahulu, apakah siap dan menerima untuk mendukung adanya work life balanceini.

Selain itu adapun alternatif lain untuk menciptakan rasa kepuasan kerja dan meminimalisir adanya konflik pekerjaankeluarga, pihak manajemen dapat menerapkan QWL (Quality of Work Life). Menurut Kaswan (2017) organisasi yang tertarik untuk menerapkan QWL karyawan biasanya berusaha menanamkan pada karyawan rasa aman, adil, bangga, kekeluargaan, demokrasi, otonomi, tanggung jawab dan fleksibilitas. Quality of Work Lifememfokuskan pada kondisi karyawan seperti keselamatan, kesehatan, dan lingkungan fisik, keadilan pemberian gaji, rasa aman karyawan, interaksi sosial, perhargaan diri, kecukupan pendapat, dan pembangunan tim. Menurut Rogelberg (2007) dampak dari adanya Quality of Work Life ini meningkatkan rasa kepuasan terhadap pekerjaan, keseimbangan antara kerja dan keluarga, dan menurunnya tingkat stres. Dari pendapat ahli diatas dapat disimpulkan bahwa diterapkannya Quality of Work Life, pihak manajemen mampu memberikan karyawan rasa puas terhadap pekerjaannya serta menyeimbangi kehidupan karyawan di dalam pekerjaan dan di dalam keluarga dengan menanamkan kebijakan berupa upah atau gaji yang memadai dan adil, program tunjangan, lingkungan yang aman dan sehat, serta ruang kehidupan yang menyeluruh seperti waktu luang bagi karyawan, pendidikan, dan kehidupa keluarga.

\section{DAFTAR PUSTAKA}

Aboobaker, N., \& Edward, M. (2017). WorkFamily Conflict and Family-Work Conflict Among Employees Across Five

Jurnal Riset Bisnis dan Investasi
Business Sectors in India-Examining The Role of Individual Differences. South Asian Journal of Marketing \& Management Research, 7 (2), 24-34.

Adhani, A. (2013).Pengaruh Kebutuhan Aktualisasi Diri Dan Beban Kerja Terhadap Prestasi Kerja. Jurnal Ilmu Manajemen, 1 (4).

Amelia, A. (2010). Pengaruh Work To Family Conflict dan Family To Work Conflict Terhadap Kepuasan Dalam Bekerja, Keinginan Pindah Tempat Kerja, dan Kinerja Karyawan. Jurnal Ekonomi dan Bisnis, 4 (3), 201-219.

Anoraga, P. (2009). Psikologi Kerja. Jakarta: Rineka Cipta.

Baltes, B.B., \& Heydens-Gahir, H. A.(2003). Reduction of work-family conflict through use of selection, optimization, and compensation behaviors. Journal of Applied Psychology, 88 (6), 1005-1018.

Bisen, V. P. (2010). Industrial Psychology. New Delhi: New Age International (P) Limited, Publishers.

Christine W.S., Megawati, O., \& Indah, M. (2010). Pengaruh Konflik Pekerjaan dan Konflik Keluarga Terhadap Kinerja dengan Konflik Pekerjaan Keluarga Sebagai Intervening Variabel (Studi pada Dual Career Couple di Jabodetabek). Jurnal Manajemen dan Kewirausahaan, 12 (2), 122-132.

Frone, M. R. (2000). Work-family Conflict and Employee Psychiatric Disorders: The National Comorbidity Survey.Journal of Applied Psychology, 888-895.

Ghayyur, M., \& Waseef, J. (2012). WorkFamily Conflicts: A Case of Employees Turnover Intention. International. Journal of Social Science and Humanity, 2 (3).

Greenhaus, J. H., \& Beutell, N. J. (1985). Sources of Conflict Between Work and 
Family Roles. Academy of Management Review, 10 (1), 76-88.

Handoko, H. T. (2009). Manajemen Sumber

Daya Manusia Cetakan IX Jilid I. Yogyakarta: BPFE UGM.

Https://bankbjb.co.id [Diakses

Februari2018]

Https://wartaekonomi.co.id [Diakses 29

Februari 2018]

Kaswan. (2017). Psikologi Industri dan

Organisasi. Bandung: Alfabeta

Kinicki., A., \& Mel, F. (2012). Organtizational Behaviour. New York: McGraw Hill

Putri, H. R. (2013). Analisis Pengaruh Stres

Kerja dan Konflik Pekerjaan Keluarga (Work Family Conflict) Terhadap Kinerja Karyawan Melalui Kepuasan Kerja Sebagai Variabel Intervening (Studi pada PT ARA Shoes Indonesia). Skripsi. Semarang: Universitas Diponegoro

Robbins, S. P., \& Timothy, A. J. (2013).

Organization Behaviour. USA: Pearson Education Inc.

Robbins, S. P., \& Coulter, M. (2012). Management. Boston: Prentice Hall.

Siagian, S. P. (2002). Kiat Meningkatkan Produktivitas Kerja. Jakarta: Asdi Mahasatya.

Soeharto, T. N. E. D. (2010). Konflik Pekerjaan-Keluarga dengan Kepuasan Kerja. Jurnal Psikologi, 37 (1).
Sugiyono. (2013). Metode Penelitian Kombinasi (Mixed Methods). Bandung: Alfabeta

Tolly, A. A. (2001). Analisis faktor-Faktor yang Mempengaruhi Turnover Intention pada Staff Kantor Akuntan Publik. Jurnal Akuntansi dan Keuangan, 3 (2), 102-125.

Wibowo. (2007). Manajemen Kinerja. Jakarta: Rajawali Pers.

Wibowo. (2013). Perilaku Dalam Organisasi. Depok: Rajagrafindo Persada.

Widyastuti, A. (2013). Kompetisi Perbankan Indonesia. Buletin Ekonomi dan Perbankan, April.

Wirakristama, R. C. (2011). Analisis Pengaruh Konflik Peran Ganda (Work Family Conflict) terhadap Kinerja Karyawan Wanita pada PT. Nyonya Maneer Semarang dengan Stress Kerja sebagai Variabel Intervening. Tesis. Semarang: Universitas Diponegoro

Yang, N., Chen, C. .C., \& Zou, Y. (2000). Source of work-family conflict: A sinoU.S. comparison of the effect of work and family demands. Academy of Management Journal, 43, 113-123.

Yousef, D. A. (2002). Job Satisfaction as a Mediator of The Relationship between Role Stressors and Organizational Commitment: A Study fron An Arabic Cultural Perspective. Journal of Management Psychology, 17 (4), 250266. 